\title{
Use and Reuse of English Books in Anglo-Spanish Collections: the Crux of Orthodoxy
}

\author{
Ana Sáez-Hidalgo
}

Firste reade, then marke, then practise that is good, For without vse, we drinke but Lethe flood.

GEOFFREY WHITNEY, Emblems, 1586

Damnant quia oderunt; oderunt, quia ignorant. BERNARDO DE SANDOVAL, Index librorum prohibitorum, 1612

The Spanish inquisitor Gaspar de Quiroga (1512-1594), in the second rule of his Index librorum prohibitorum, established that

Prohibense los libros de los heresiarchas: assi los que del dicho año de mil y quinientos y quinze à esta parte han sido inuentores, o renouadores de las heregias, como las cabeças y capitanes de ellas [...]. Pero no se prohiben los libros de Catholicos, aunque anden i esten insertos en ellos los tractados de los dichos Heresiarchas, contra quien escriuen. ${ }^{1}$

* I'm grateful to Victor Houliston, James E. Kelly, Christopher Warner, Maurice Whitehead and R.F. Yeager for their insightful readings of my essay. Special thanks are also due to José Luis del Valle Merino, director of the library of El Escorial, and to the rest of the staff, for their help during my research.

1 Quiroga Gaspar de, Index et catalogus librorum prohibitorum (Madrid: Alphonso Gómez, 1583) $1 \mathrm{r}-\mathrm{v}$; my translation from Spanish to English, here and elsewhere (unless otherwise stated). This rule is based on the Tridentine Index (1564). 
[The books by heresiarchs, both those who have invented or renewed heresies in and after 1515, and their leaders and champions are forbidden [...]. But books by Catholics, even if they include treatises by those heresiarchs against whom they write, are not forbidden.]

Quiroga, as Grand Inquisitor, had papal-delegated authority to fight heterodoxy through an apparatus of institutional repression, a branch of which was dedicated to controlling and suppressing those books that fell in the category defined by the Church of Rome as 'heretic'. This qualification to the prohibition of deviant texts was necessary so that Catholics alluding to their religious opponents would not find their own books cancelled. This was a special concern for all those who had to engage in religious polemics, because often the best way to counter-argue the 'heretics' was by reprinting their ideas, texts and arguments verbatim.

English Catholics were particularly in need of this rule. They were among the first who, after the spread of Reformation, received a special dispensation from the pope to write controversy against specific Protestant arguments and concepts. ${ }^{2}$ While suffering the Elizabethan ban on the publication and trade of Catholic books, it was their situation of persecution and the need to refute their religious opponents that persuaded authorities like Claudio Acquaviva to direct that the printing press might be used by the English mission 'for the defence of the faith and the edification of Catholics.' ${ }^{3}$ Such a directive boosted what had already begun to be a vigorous underground activity of production and dissemination of books in England. Seminaries in exile had a crucial role in this activity: not only were they producers and users of these materials for their training in controversy, but their staff and students were also part of the networks that facilitated the distribution - and often the smuggling - of many of these volumes, both in print and manuscript form. ${ }^{4}$

2 Walsham A., "The Spider and the Bee: The Perils of Printing for Refutation in Early Tudor England", in King J.N. (ed.), Tudor Books and Readers: Materiality and the Construction of Meaning (Cambridge: 2010) 163-19o, here 175 .

3 McCoog T. M., "'Guiding Souls to Goodness and Devotion': Clandestine Publications and the English Jesuit Mission", in Bela T. - Calma C. - Rzegocka J. (eds.), Publishing Subversive Texts in Elizabethan England and the Polish-Lithuanian Commonwealth (Leiden: 2016) 91-109, here 108.

4 On the role of English colleges in Spain in the dissemination and production of texts related to their mission, see Sáez-Hidalgo A., "English Recusant Controversy in Spanish Print Culture: Dissemination, Popularization, Fictionalization", in Chambers L. and O'Connor T. (eds.), Forming Catholic Communities: Irish, Scots and English College Networks in Europe, 1568-1918 (Leiden: 2018) 201-231. Chambers' and O'Connor's book provides a very complete view on colleges in exile in the early modern period. More specific on the connection of the English 
This essay will study the co-existence of orthodox and heterodox material in a copy of The Second Part of Christian Exercise now at the Royal Library of El Escorial, in Spain. Annotations and markings left in it by various hands cast light on the reception of English books in Spain, as well as on the channels facilitating their dissemination. No less importantly, the marked volume offers clear and unique evidence of how Catholics in exile dealt with their difficult circumstances by repurposing such texts as came to hand, not only Catholic, but also Protestant texts. Although their engagement with texts of the 'other' might be expected to be overtly hostile and combative, this essay testifies to a wider range of practical-minded reading practices in response to the exigencies of the situation of exile and persecution when it came to books.

The Royal library of El Escorial is a good instance of how the coexistence of the orthodox and heterodox travelled beyond the British Isles to the Iberian Peninsula. There is, among its holdings, a notable number of English works, both of Catholic and Protestant origin. Thanks to the networks of English Colleges on the Continent, these books ended up on the shelves of what Luis Gómez Canseco has described as a 'reproducción en miniatura de la España teológica del XVI y de sus polémicas religiosas 5 [a miniature reproduction of sixteenth-century theological Spain and its religious polemics]. Though largely referring to the conflicting Spanish Counter-reformation groups, Gómez Canseco notes the existence of footprints of Erasmian humanism in the library of El Escorial, the monastery founded by Philip II as a major propagandistic device to proclaim Philip's power, his political, military, and religious - i.e., Catholic - power. ${ }^{6}$ Yet, somewhat counterintuitively, despite his projected personal image as bulwark of Catholicism, Philip imagined a library replete with universal, and therefore inclusive, knowledge, opening the doors to all kinds of topics, ideologies and beliefs. Hence, a large variety of English titles appear in the collection: from histories like William Camden's Britannia to medical treatises (Timothy Bright's Therapeutica) or language handbooks (John Cheke's De pronuntiatione graecae); ${ }^{7}$ from some of the central works of the Elizabethan

mission and the Spanish context is McCoog T.M., The Society of Jesus in Ireland, Scotland and England, 1589-1597. Building the Faith of St Peter upon the King of Spain's Monarchy (Leiden: 2012).

5 Gómez Canseco L., El humanismo después de 16oo: Pedro de Valencia (Sevilla: 1993) 36.

6 Ibidem 162ff. The main source of this Erasmian influence was the humanist Benito Arias Montano, who was one of the earliest librarians at El Escorial. See also Gonzalo SánchezMolero J.L., "La biblioteca de Arias Montano en El Escorial", in Maestre Maestre J.M. et al. (eds.), Benito Arias Montano y los humanistas de su tiempo, vol. 1 (Mérida: 2006) 91-110.

7 Camden William, Britannia (Frankfurt, John Wechel: 1590); Bright Timothy, Therapeutica (Frankfurt, John Wechel: 1589); Cheke John, De pronuntiatione graecae (Basel: Nicholas Episcopius jr.: 1555). 
Established Church, like Foxe's Actes and monuments (popularly known as the Book of Martyrs) and the Booke of common prayer, ${ }^{8}$ to others at the heart of Catholic orthodoxy, among them books by the famous controversialists Thomas Stapleton and Nicholas Sander, or by the leaders of the English mission, William Allen and Robert Persons. ${ }^{9}$ Given that there was no restriction on the acquisition or inclusion of new titles into the Escorial library, it was part of the job of the prior of the monastery and the director of the library to examine this mixed variety of texts, and decide which to label as forbidden, so that they would not be accessible to unauthorized readers, by placing them in a separate room, rather than censoring and expunging them. ${ }^{10}$

In this regard, the royal library attests to how unstable the perception of the fine line between orthodoxy and heterodoxy could be. This can be clearly illustrated in the works by English authors like Persons, one of the main controversialists in defence of the Catholic faith in England, and actively involved in the establishment of a network of English Catholic Seminaries on the Continent, including Spain. ${ }^{11}$ While some of his books were incorporated into the collection without any impediment (the so-called 'Philopater', as well as a number of texts connected to the English mission), ${ }^{12}$ others were listed as prohibited, including what is considered to be his main devotional and most widely successful work, The Christian Directory. ${ }^{13}$ Surprisingly, the main motive for this

8 Foxe John, Actes and monuments (London, Iohn Day: 1563). The Booke of common prayer (London, Christopher Barker: 1578).

9 A brief overview of early modern English books at the Escorial library is provided by Ana Sáez-Hidalgo in "Extravagant' English Books at the Library of El Escorial and the Jesuit Agency", in Kelly J.E. - Thomas H.J. (eds.), Jesuit Intellectual and Physical Exchange between England and Mainland Europe, c.1580-1789. 'The World is our House'? (Leiden: 2019) $155^{-185}$, here $15^{6-159}$.

10 Lezcano Tosca H., "Lecturas espirituales prohibidas en la Real Biblioteca de El Escorial (siglo XVI)", Libros de la Corte.es 6 (2013) 76-120, here 88-9o. Many of the books with censored passages had been expunged prior to their incorporation to the library.

11 Persons founded the Colleges of St Alban's in Valladolid (1589), and St Gregory in Seville (1592). On Persons's role for the English mission and his works, see Houliston V., Catholic Resistance in Elizabethan England: Robert Persons's Jesuit Polemic, 1580-1610 (Aldershot: 2007), and Carrafiello M.L., Robert Parsons and English Catholicism, 1580-1610 (Selinsgrove: 1998).

12 These are works edited, compiled or translated by Persons: Relacion que embiaron las religiosas del Monesterio de Sion de Inglaterra (Madrid, biuda de P. Madrigal: 1594), and Relacion de un sacerdote ingles, escrita a Flandes, a un cavallero de su tierra, desterrado por ser catolico (Madrid, Pedro Madrigal: 1592).

13 The copy at the Royal library is from the third edition: A christian directorie guiding men to their salvation devided into three boores [i.e. bookes] (Louan, Laurence Kellam: 1598). 
prohibition has to do, not so much with the kind of devotion encouraged by Persons, but rather with other books that were concurrently acquired for the royal library and listed as forbidden at El Escorial. One such is The Second part of the Booke of Christian exercise, appertayning to Resolution or a Christian directory, guiding all men vnto theyr saluation. ${ }^{14}$ Though in appearance a continuation of Persons's Christian Directory, it is however a Protestant reformulation, designed to turn to Protestant advantage the popularity of Persons's original text. It was unlikely to be missed by the censor, whose zeal for orthodoxy would however put both texts into the same category. This coexistence of orthodox and heterodox texts is the background against which this essay intends to study the Escorial copy of the spurious Christian Directory - The Second part of the Booke of Christian exercise, a volume of particular interest because it has been heavily annotated. The marks and annotations in the book will help us explore the manner in which readers dealt with religious otherness.

Before proceeding to the analysis of the volume, however, it is helpful to review the convoluted story of Persons's Christian Directory. Having written the introduction to the English translation of Gaspar Loarte's Essercitio della vita cristiana ${ }^{15}$ the English Jesuit decided to expand it into a complete work in order 'to persuade a Christian by name, to become a trewe Christian in deed, at the least, in resolution of mynde.. ${ }^{16}$ The resulting book was published anonymously in 1582 with the title First booke of the Christian exercise, appertayning to resolution. Wherein are layed downe the causes \& reasons that should moue a man to resolue hym selfe to the seruice of God, popularly known as 'Resolution'. ${ }^{17}$ Brad G. Gregory has adroitly summarized what came next:

\footnotetext{
14 The Second part of the Booke of Christian exercise, appertayning to Resolution or a Christian directory, guiding all men vnto theyr saluation (London, Iohn Charlewood: 1592).

15 Loarte Gaspar, The Exercise of a Christian Life, trans. Stephen Brinkley (London, W. Carter: 1579).

16 I use Victor Houliston's edition here and elsewhere, unless some specific aspects of the Escorial copy need to be referred to: Robert Persons S.J.: the Christian directory (1582): The first booke of the Christian exercise, appertayning to resolution (Leiden; Boston: 1998). On Persons's initial plan for the Directory, see his letter to Claudio Acquaviva on 12 February 1585 (Persons Robert, The Correspondence and Unpublished Papers of Robert Persons, SJ. 1, 1574-1588, ed. V. Houliston [Toronto: 2017], 564-570).

Published in Rouen in Persons's Press.
} 
[Persons's Resolution] was so much appreciated by a Puritan minister and preacher, Edmund Bunny, that the latter issued his own, amended version of the work in 1584. It is a treatise of more than 400 pages which attempts to persuade its readers to live diligent Christian lives. Perhaps the most popular devotional treatise in late sixteenth-century England, there is at least anecdotal evidence that it had considerable impact. Its publication record is impressive: previous to 1600 , Parsons's [sic] version had been published four times, the full text of Bunny's version twenty-four times, and a partial edition of Bunny's another six, a total of thirty-four editions in eighteen years. ${ }^{18}$

Bunny's Booke of Christian exercise was an appropriation - or, as he put it, 'perusal' - of the Resolution, though not as radical as one might expect in the context of the harsh polemics and controversies between Catholics and Protestants. ${ }^{19}$ Rather than implementing major changes by replacing certain words and phrases, or putting them in parenthesis, Bunny's method worked at a microlevel to redirect the reading of the text. ${ }^{20}$ As has been variously studied, this type of alteration, while showing some basic doctrinal disparities between the two churches, ${ }^{21}$ is revealing of both Persons's and Bunny's common interest in ensuring that readers/believers were rigorous in their practice of religion..$^{22}$

18 Gregory B.S., "The 'True and Zealouse Service of God': Robert Parsons, Edmund Bunny, and the First Booke of the Christian Exercise", Journal of Ecclesiastical History 45 (1994) 238-268, here 239. V. Houliston has studied Persons's process of composition of the Christian Directory in Catholic Resistance in Elizabethan England 23-45.

19 Booke of Christian exercise, appertaining to resolution [...] by R.P. Perused, and accompanied now with a treatise tending to pacification: by Edm. Bunny (London, N. Newton: 1584).

20 As Houliston has pointed out, Bunny 'welcomed an apparent suspension of controversialist hostility, and assumed a common goal of sincerity in religion' ("Why Robert Persons Would not Be Pacified. Edmund Bunny's Theft of The Book of Resolution", in McCoog T.M. (ed.), The Reckoned Expense: Edmund Campion and the Early English Jesuits (Woodbridge: 1996) 159-177, here 169); Sullivan C., "Cannibalizing Persons's Christian directorie, 1582", Notes \& Queries 41 (1994) 445-446; Houliston V., "Persons Cannibalized Again", Notes \& Queries 44 (1997) 32-33; Corthell R., "Writing Back: Robert Persons and the Early Modern English Catholic Subject", Philological Quarterly 87, 3-4 (2008) 277-297.

21 It's generally agreed that these differences are relatively mild. Houliston boils them down to different notions of exercise ("Why Robert Persons would not be pacified" 173). For a detailed list of Bunny's changes to the text, see R. McNulty's collation of Persons and Bunny (Robert Parsons's The First Booke of the Christian Exercise (1582). An Edition and a study, Ph.D. dissertation, Columbia University: 1955), and more recently, Houliston's critical edition, which includes all of Bunny's modifications.

22 Gregory, "The 'True and Zealouse Service of God" 252ff. Houliston "Why Robert Persons Would not Be Pacified" $169 f f$. R. McNulty has argued that actually Persons intended to 
Bunny's publication, which caught Persons preparing a revised, expanded edition for print, enraged the English Jesuit because, in his own words, it made him 'speake like a good minister of England'. ${ }^{23}$ Persons's reaction to such a manipulation can be read in the preface to his own second edition, whose title was changed into A Christian directorie guiding men to their saluation. ${ }^{24}$ Clearly offended, Persons denounced the 'foule and false dealing of M. Edm[und] Buny Minister', in a rebuttal of Bunny's changes which occupies some of the margins of the Christian Directory. This episode added a new tone to Persons's revised version; as Victor Houliston has pointed out, 'rhetorically speaking, The Book of Resolution is deliberative: it exhorts the reader to decision and action. A Christian Directory, with two lengthy chapters inserted early in the text, veers towards the forensic: it deals with proof rather than motive, ${ }^{25}$ using what could be considered a more polemical mode.

The volume at El Escorial is not Bunny's Booke of Christian exercise, but a later, anonymous Protestant appropriation of Persons's 1585 The Christian Directory, under the title The Second part of the Booke of Christian exercise. This new appropriation of Persons has received scant critical attention despite its contemporary popularity: it was printed more than twelve times in less than fifty years. ${ }^{26}$ The Escorial copy is a 1592 edition of The Second part, which was first published in 1590 as an update to Bunny after Persons revised and enlarged his own work into the Christian Directory, as is stated in the preface to the reader:

Gentle Reader, not manie yeeres since, a booke was published of Christian exercise, appertaining to Resolution: written by a Iesuit beyonde the Seas, yet an English-man, named Ma. Robert Parsons, which Booke, Ma. Edm. Bunney hauing dilligently perused, committed to the publique viewe of all indifferent iudgements: as glad that so good matter proceeded from such infected people, and that good might arise thereby to the benefite

persuade not only Catholics, but also Protestant, to 'the good life of God's way' ("The Protestant Version of Robert Parsons' The First Booke of the Christian Exercise", Huntington Library Quarterly 22 (1959) 271-30o, here 272).

23 I cite from the original 1585 edition, page 11 (see following footnote for bibliographical details). Houliston suggests that some rumour of Bunny's hacking must have reached Persons while still revising his text, rather than at the moment of printing, as he claims in the preface of the ${ }_{5} 85$ Christian Directory (Houliston, ed. xxix).

24 [Rouen, Persons's press]: 1585.

25 Houliston "Why Robert Persons Would not Be Pacified" 174. See also his "Re-Considering 'Consideration' with Robert Persons", Reformation 24, 1 (2019) 24-42. I'm grateful to Prof. Houliston for letting me see a pre-print copy of this article.

26 For a list of all the reprints of the work, see Houliston The Christian Directory lvi-lvii. 
of others. Since the manifestation of that booke, the first Author thereof, named Ma. Parsons, hath enlarged the same Booke, with a second part and new additions [...]. And considering howe diuers were desirous to haue thys latter part, because they had thorowlie read the other: after passage the perusing of sundrie learned men, who haue thought it as worthy to be seene as the first, it is (gentle Reader) presented to thy viewe, reade it indifferentlie, and iudge therof as thou findest occasion. ${ }^{27}$

Experts agree that Bunny was not involved in this new version, and it remains unclear who the 'sundrie learned men' might have been..$^{28}$ In any case, this new Protestantization differs in method from Bunny's. Firstly, as John P. Driscoll has observed, The Second part peruses selectively, that is to say, it includes only some of the sections of Persons's revised text, leaving out more than half of the work. Driscoll speculates that the volume was intended to supplement Bunny's - actually, several extant copies are bound with it - and therefore only the new material needed to be 'perused'. ${ }^{29}$ Secondly, a sizeable passage has been added in the chapter on 'Howe a man may iudge or discerne of himselfe, whether he be a true Christian or not. With a declaration of the two parts belonging to that profession: which are, beleefe and life' ${ }^{30}$ This substantial intervention, of more than thirty pages, had three main aims, in Driscoll's view: the obliteration of the Catholic notion that instruction through churchmen was relevant for the faith; the centrality of the Scriptures for the faith; and the clarification of the connection between faith and good works. Finally, the rest of the modifications to Persons's text range from those typically Protestant alterations, similar to Bunny's (e.g., erasing words like 'Pope'31 or diminishing

27 I'm citing from the first edition: The Seconde parte of the Booke of Christian exercise, appertayning to Resolvtion. Or a Christian directorie, guiding all men to their saluation (London, Iohn Charlwoode and Simon Waterson: 159o) n.p.

28 Driscoll J.P., "The Seconde Parte: Another Protestant Version of Robert Persons's Christian Directorie", Huntington Library Quarterly 25 (1962) 139-146. Houliston, Christian directory lv-lviii.

29 Driscoll, "The Seconde Parte" 140-142.This argument is questionable, however: after stating that the rationale for selection is doctoring Persons's new material, Driscoll admits that some chapters that were not entirely new are included in this book.

30 The Seconde parte of the Booke of Christian exercise (1590) 343-376; for the edition examined in this essay, published in a smaller format, The Second part of the Booke of Christian exercise (1592) 427-462. Henceforth, references to this edition will be abbreviated as The Second part (1592) in footnotes to distinguish it from other editions, which will also be cited with their date for clarity.

31 Surprisingly, however, the term 'Catholic' is not entirely eliminated, as Driscoll has noted, which he attributes to the new editors' acquaintance with the notion that the term Catholic applied both to the Anglican and the Roman Church (143). 
the importance of good works to gain heaven), to a high number of what can be considered lexical minutiae, conceivably of smaller doctrinal consequence than those taken up by Bunny: often grammatical choices like the substitution of the article 'an' for 'the', or 'that' for 'the', ${ }^{32}$ changes in prepositions (depart out of > depart from), the addition of the conjunction 'and' instead of a comma, or verbal tenses ('asked' instead of 'asketh'). ${ }^{33}$ At other times the changes seem to reflect lexical preferences: choosing 'words' over 'speeches', 'following' instead of 'ensuynge, ${ }^{34}$ or in expressions like 'God shal take flesh in a womans wombe' where Persons had used 'God shall take flesh in a womans bellie'.35 Although Driscoll has analysed the main features of The Second part, a more exhaustive study is still needed to assess this combination of doctrinally driven changes and those apparently focused on grammatical and stylistic aspects. While a thorough examination of the detail of these modifications is beyond the scope of this essay, their broader features will be of significant relevance for clarifying the annotations in the El Escorial copy of The Second part, examined in detail below.

The 1592 edition of The Second part - the one at El Escorial - was printed in a very small format, duodecimo, making the book a commodity that could be easily carried around, whether for habitual private usage or for smuggling. The inexpensive parchment binding of the Escorial copy suggests use as a budget pocketbook, which was doubtlessly facilitated by the fact that it is bound by itself, not together with Bunny, as was frequently the case. Also, although the book is quite well preserved, probably it endured frequent reading. ${ }^{36} \mathrm{~A}$ sticker on the spine, 'viij.Proh.32', indicates that it was allocated to the 'high chamber' of the Escorial library, where the forbidden books were kept. Yet despite the fact that the contents of the volume justify its prohibition, surprisingly The Second part was not and would never be included in any of the indexes of forbidden books issued by the Catholic Church in Spain or Rome. In contrast to any work by Bunny (an 'auctor damnatus', all of whose works were automatically

\footnotetext{
32 The Second part (1592) 400-401.

33 Ibidem 66.

34 Ibidem $28,82$.

35 Both terms were used at the time for what we nowadays refer to as female womb in pregnancies. See LEME (Lexicons of Early Modern English), available at https://leme.library .utoronto.ca/search/quick (last accessed 1 May 2020).

36 This is shown by the fact that cords holding the binding are now lost.
} 
banned), no official document condemned The Second part. ${ }^{37}$ Moreover, the Escorial library was a special case, given the vast number and variety of titles in it. As a result, the inquisitors often had to rely on their own sense of what was permissible or not, because the indexes fell short for its holdings: not every book in it had been subject to the inspection of the authorities in charge of making the list of forbidden books.

The relegation of the Escorial copy of The Second part to the 'high chamber' of forbidden books would seem inextricably connected to how the volume became part of the royal library. Although the exact date of its incorporation into El Escorial is unknown, it is part of a small collection of books, most of them English, which were added to the royal collection between the 1610 and 1635 , and which were labelled on their title-pages as 'extravagant'. ${ }^{38}$ Such labelling must have led to their inclusion in a 1635 list of forbidden books in the Library of El Escorial. All of these titles were (and remain) grouped together, but outside the usual inquisitional categories ${ }^{39}$ as works 'comprehendidos en alguna de las reglas generales del índice de los prohibidos' 40 [comprised in some of the general rules of the index of forbidden books], meaning that even if they were not specifically listed in the indexes, the general rules of the inquisition could apply to them. In the case of The Second part, its Anglican nature makes it clearly eligible for this list. But this small group is in fact a heterogeneous collection which not only includes works by 'heretical' authors like Richard Bancroft, John Norden and Richard Turnbull, ${ }^{41}$ but also Catholic books like the Douay edition of The miroure of the blessed life of our Lorde and Sauioure Iesus Christe (ca. 16o6), translated by Nicholas Love, and two works by Persons, the abovementioned Christian Directory and A briefe apologie, or Defence of the Catholike Ecclesiastical Hierarchie (1601). ${ }^{42}$ Probably their orthodoxy went unnoticed by inquisitors, who, observing that they were written in English,

37 Cf. Martínez de Bujanda J., El índice de libros prohibidos y expurgados por la Inquisición española (1551-1819) (Madrid: 2016); Martínez de Bujanda J. et al. Thesaurus de la littérature interdite au XVIe siècle: auteurs, ouvrages, éditions avec addenda et corrigenda (Paris: 1996).

38 For a complete analysis of this collection, see Sáez-Hidalgo, "Extravagant' English Books at the Library of El Escorial" $155^{-185}$.

39 These categories are: 1) all the works by an 'auctor damnatus' [banned author], 2) specific works by a banned author, and 3) specific writings by specific authors.

40 "Memoria de los libros prohibidos guardados en la biblioteca de El Escorial", fol. 12v.

41 Bancroft Richard, A suruay of the pretended holy discipline (London, Iohn Wolfe: 1593). Norden John, A pensiue mans practise, verie profitable for all persons (London, Robert Robinson: 1597). Turnbull Richard, An exposition vpon the canonicall epistle of Saint Iames (London, John Windet: 1591). 
the language of 'heretics' (and one that inquisitors in Spain typically couldn't read), unhesitatingly put them in the same category as the rest, effectively banning them.

All the books in this small collection belonged originally to various Englishmen who were in Seville at the turn of the century, three of whom have been identified: Thomas Pitt, James Wadsworth and John Price. ${ }^{43}$ These men - respectively a merchant, a convert, and a recusant - not coincidentally come from three of the dominant networks of material and cultural exchange between the British Isles and Spain. ${ }^{44}$ Their activities also encompassed the circulation of English books into and within Spain. More specifically: Wadsworth worked for the Spanish Inquisition after his conversion, and was involved in the inspection of the books that were confiscated in the searches of English boats. The staff of St Gregory's English College - men such as Price - were also involved. ${ }^{45}$ Both Wadsworth and Price had a role in the inquisitorial scrutiny of some of the Anglican books in the collection that ended up in El Escorial, and at least one of the volumes - if not more - belonged to Pitts, a merchant of the Spanish Company. ${ }^{46}$ Apparently, for whatever reason, these Anglican books subject to inspection were never returned to the Inquisition, but instead remained in the hands of Wadsworth and Price, who must then have merged them with the Catholic titles in their own collections. ${ }^{47}$ This is clearly how these heterogeneous works were brought together. Abnormal though this may seem, the fact that books considered orthodox and heterodox coexisted in private Catholic collections was not uncommon in the period. As we have already seen, Catholics had permission to refute heretics, and that required them to have the original texts. This was especially the case in English Colleges in exile like the one in Seville, where prospective seminary priests were trained in polemical theology. For instance, records show that the purveyor Richard

43 Murphy G.M., "Wadsworth, James (c. 1572-1623)", Oxford Dictionary of National Biography. 23 Sep. 2004; Accessed 15 Jan 2020. https://www.oxforddnb.com/view/10.1093/ ref:odnb/978o198614128.oo1.ooo1/odnb-978o198614128-e-28389. On Price, see McCoog T.M., English and Welsh Jesuits: 1555-1650 ([London]: 1994) s.n. Price.

44 On English merchants in Spain see Alloza Á., "Comercio y rivalidad entre España e Inglaterra. Corso, ataques navales y represalias en los siglos XVI y XVII", XVII Coloquio de Historia Canario-americana (Las Palmas de Gran Canaria: 2006) 1642-1688; Croft P., "Trading with the Enemy, 1585-1604", Historical Journal 32, 2 (1989) 281-302.

See Croft P., "Englishmen and the Spanish Inquisition", The English historical Review 87, 343 (1972) 249-268. On the collaboration of the English College with the Inquisition, Murphy M., St Gregory's College, Seville, 1592-1767 (London: 1992) 10-12, 124-125.

46 On Thomas Pitt, see Sáez-Hidalgo, “'Extravagant' English Books at the Library of El Escorial" $166-168$.

Ibidem 165-166. 
Verstegan distributed copies of Bunny's works to St Gregory's College in Seville. ${ }^{48}$ Other Catholic libraries had copies of Protestant books, from prison libraries to nuns' collections. ${ }^{49}$ Ownership of Catholic books by Protestants was relatively common as well, as Alexandra Walsham and Earle Havens have surveyed. ${ }^{50}$

It is therefore in this atmosphere of fluidity in the dissemination and usage of Catholic and Protestant texts (noted by John Yamamoto-Wilson ${ }^{51}$ ) that the El Escorial copy of The Second part of the Booke of Christian exercise and its annotations should be contextualized. Though its arrival in the Peninsula is not documented, it could have been one of the books sent by agents like Verstegan to the English Colleges for their exercises in controversy; alternatively, the book might have reached Spain by means of one of the many English Protestant merchants whose properties were searched, and on being discovered, subsequently handed over to an English collaborator of the Inquisition like Wadsworth or Price. Be as it may, the annotations that pervade the volume are a rare instance of the reading and the usage that this English book had in Spain at the turn of the century. ${ }^{2}$

48 Stonyhurst College, Ms. Coll. B.137; CRS 52:187-189. The volume has been identified as Bunny's A briefe answer, vnto those idle and friuolous quarrels of $R[$ obert $] P[$ ersons $]$ against the late edition of the Resolution (London, Iohn Charlewood: 1589). On Verstegan as distributor of Catholic texts between England and the Continent, see Arblaster P., Antwerp $\&$ the World. Richard Verstegan and the International Culture of Catholic Reformation (Leuven: 2004) 47-66.

49 Some instances include Stephen Vallenger's library, which owned copies of Bunny's Protestantized version of Robert Persons's Booke of the christian exercise (1584), and William Fulke's exhaustive refutation of the Rheims New Testament (1589) (Walsham A. Havens E., "Catholic Libraries: An Introduction", in Fehrenbach R.J. et al (eds.), Private Libraries in Renaissance England: A Collection and Catalogue of Tudor and Early Stuart Book-Lists, vol. 8 (Tempe: 2014) 129-261, here 145. See also Bowden C., "Building Libraries in Exile: The English Convents and their Book Collections in the Seventeenth Century", British Catholic History 32, 3 (2015) 343-382, here 362-363.

$5^{\circ} \quad$ "The perusal of "popish" books by learned readers for scholarly purposes was regarded as permissible, for instance, and Protestant divines such as William Crashaw, Richard Bancroft, and Tobie Matthew regularly acquired copies for their libraries' (Walsham Havens, "Catholic Libraries", 133).

$51 \quad$ Yamamoto-Wilson J.R., "The Protestant Reception of Catholic Devotional Literature in England to 1700", British Catholic History 32, 1 (2014) 67-9o. See also his "Robert Persons's Resolution (1582) and the Issue of Textual Piracy in Protestant Editions of Catholic Devotional Literature", Reformation and Renaissance Review 15, 2 (2013) 177-198.

$5^{2}$ No other copy of The Second part has, to my knowledge, such a large number of annotations throughout the volume, nor even if some of them have some marginalia and reading marks. 
Clues to the reading and usage of the volume are offered by several annotating hands. The first two appear on the verso of the flyleaf, translating the title of the work: 'la $2^{\mathrm{a}}$ parte de un libro / inglese llamado / la Resolution / [2nd hand]] o cristiano directorio que guia / los ho[mbr]es a su saluacion', a rendering that was probably used to make the abovementioned list of El Escorial forbidden books, put together in 1635 . Other notes have a similarly pragmatic purpose. In several places the volume is mis-paginated, and one of the readers has noticed that it is not a printer's typo: the quire starting after page 312 must have been wrongly folded, so a note warns 'see 4 leafes after', and at the end of the quire, before page 321 , we read again 'see 4 leaves before' ${ }^{53}$ Whether these notes are a reminder for the reader's own guidance or for other possible readers is difficult to tell, but in any case, they show an attentive and thorough usage of the book.

An equivalent thoroughness is perceptible in the rest of the annotations in the book. Underlinings and crossing-outs of individual words or phrases, insertions and corrections of one or several words, sometimes between the lines and sometimes in the margins, transposition of elements and some other readers' marks, all of which show attentive reading of The Second part. Unfortunately, nowhere in the text can any indication be found of the purpose of such an extensive apparatus of hundreds of annotations, written in a hand perceptibly different from the one translating the title in the flyleaf.

A number of factors suggest that the annotations very likely were made before the volume was incorporated into the Escorial library. Clearly, they were not part of an inquisitional expunging. As we have seen, The Second part was never included in any of the Holy Office indexes, and therefore no official guidelines existed for its censorship. It is certainly true that it is possible to find other instances of purged books that had never been on the index librorum prohibitorum. The most famous probably being the so-called 'Inquisition Folio' of Shakespeare's works, now at the Folger Library. This is a censored copy of a second folio that at one time belonged to the library of the Royal English College of St Alban, in Valladolid, Spain. According to a manuscript note on the title-page, ${ }^{54}$ the book was expunged by William Sankey, who took the initiative

53 The pages appear in the following sequence: $317,318,319,320,313,314,315,316$, therefore the first two leaves of the quire had been folded onto the back of it. The same happens with the quire after page 328 .

54 'Opus auctoritate Sancti officij permissum et expurgatum eadem auctoritate per Guilielmum Sanchaeum e Soc<ieta $>$ te Jesu'. Mr. VVilliam Shakespeares comedies, histories, and tragedies (London: Thomas Cotes, 1632). See the catalogue of the Folger library: http://luna.folger.edu/luna/servlet/s/h749j2. 

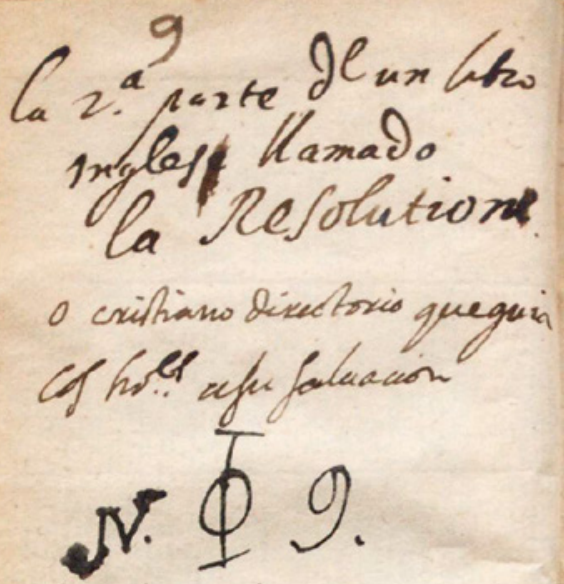

$3 y j-1 / 11-633$.

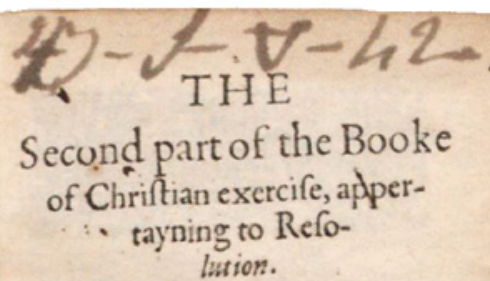

OR

A Chriftian directory, guiding All men Gnto theyr fal. wation.

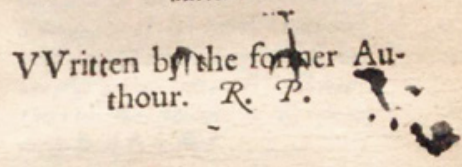

PS A I M. 27. ver. 4.

One thing haue I requeited of the Lorde, and that will I demaund ftil, which is, to dwell in his houfe all the dayes of mylyfe : to the ende I may knowe and doe his will.

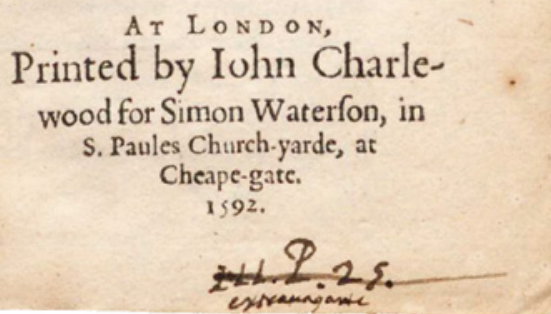

FIGURE 7.1 The Second part of the Booke of Christian exercise (London, Iohn Charlwood for Simon Waterson: 1592) title-page. Royal Library of the Monastery of El Escorial (C)PATRIMONIO NACIONAL

following his own interpretation of the Holy Office guidelines as to what is orthodox or heterodox. ${ }^{55}$ That statement on the title-page renders it an officially acknowledged inquisitorial intervention. The Escorial copy of The Second part has no such statement, however, nor the traditional 'visus' note indicating its examination by the authorities and the date, either [Fig. 7.1]. Moreover, the method used to cross out passages in the Escorial Second part is very different 
from the Inquisition's: The Holy Office required that the expunged text be completely obliterated. Censors resorted to crossing out the lines in such a way as to render the text impossible to read it at all and even to excise passages. ${ }^{56}$ By contrast, the crossed-out (and underlined) elements in the Escorial copy of The Second part are struck through with a single, thin horizontal line that does not prevent the original to be read. Indeed, a replacement in the margin often accompanies such strike-throughs - a practice altogether inconsistent with the methods traditionally used by the Inquisition. These marks and annotations are thus a key to the kind of reading that the Escorial copy of The Second part received. Far from censoring the text, such markings show a reader or readers reacting and responding to the text thoughtfully, and in several ways.

Conceivably, given that the book belonged to English Catholics in exile before it reached the shelves of El Escorial, these marks and annotations might evince an exercise in refutation, ${ }^{57}$ a practice common in print and in manuscript, which usually entailed presenting the original text and the response to it side by side. ${ }^{58}$ Certainly, in the Escorial copy of The Second part more than one deletion and its corresponding annotation would be compatible with this possibility. In the section discussing 'the ende and cause' of man's creation, for example, the text reads:

why, and wherefore, and to what end, [man] was created \& sent hether into this world? What to do? [...]

And then shall he finde, that for no other cause, matter, or end, but onely to serue God in thys lyfe, and by that seruice to enioy heauen, and euerlasting saluation in the lyfe, to come..$^{59}$

The anonymous hand has underlined 'enioy', writing 'gaine' in the margin as a substitute for it. This recurs three pages later, once with identical lexical pairs (gain/enjoy), and once to correct 'possess', with 'gaine' written in the

$5^{6}$ This may be the most habitual method, although more radical measures were sometimes carried out, from gluing pieces of paper to cutting out the pages, as in the Folger Inquisition folio, where Mesure for Measure is entirely cut off.

On the practice of disputation at English Colleges, see McCoog T.M., "Playing the Champion': The Role of Disputation in the Jesuit Mission", in McCoog, The Reckoned Expense 119-140.

$5^{8}$ Walsham "The Spider and the Bee" $163^{-190}$. This format somehow reminds the notion of book usage described by Stephen B. Dobranski, that is, books that were specially prepared to be completed by readers: Readers and Authorship in Early Modern England (Cambridge - New York: 2005).

The Second part (1592) 157. 
margin, in the phrase 'when of possessing Gods eternall kingdom'.60 These corrections seem intended to contest a more Protestant view of salvation and provide instead the Catholic notion that heaven can only be won as a result of one's actions.

Similarly, this same notion seems to be behind one of the longest passages cancelled and then replaced by a different text in the margin. In the section intended to help the reader discern 'whether [a man] be a true Christian or not', the first point urges belief in the Bible and the mysteries of Jesus, his disciples and the Church, and to

perswade \& assure himselfe, of the forgiueness of all hys sinnes, and of the fatherly loue and fauour of GOD towardes hym in Christ Jesus, whereby he is adopted to be the sonne of God, and heire of euerlasting life. ${ }^{61}$

This passage is entirely crossed out, and the anonymous hand has written in the margin a new version:

[...] performe in sincerity the rules and precepts of life, prescribed vnto Christians for direction of their actions. ${ }^{62}$

Again, this modification emphasizes the necessity of good actions as a requisite for salvation defended by Catholics, versus the Protestant notion found in the Second part, that God's 'fatherly love and favour' can be enough - if not, indeed, all.

Other marginalia convey a similar Catholic response to the text of The Second part. For instance, the terms 'repentance' and 'repent' are frequently eliminated and replaced by 'penance' and 'do penance', ${ }^{63}$ thus encapsulating in a verbal difference a major doctrinal disagreement between the two creeds. Also, a reference to the Papal Curia makes its appearance in the margin, where 'The sea Apostolicke' replaces 'that rule':

6o Ibidem 16o.

61 Ibidem 423.

62 Ibidem.

63 See, for instance, on Jesus' divinity: 'Let vs now compare the Proclamation of Iesus, whose enterance [sic] and Praeface was: Paenitentia $[\mathrm{m}]$ agite, Repent yee' (354), where 'Repent' is replaced in the margin by 'doe ye pena[n]ce'. Also, The Second part says on the Christ's Sermon on the Mount: 'he talketh of nothing els [sic] but of vertuous lyfe, pouertie, meekenes, iustice, purity, sorrow for sinne, patience in suffering, contempt of ryches, forgiuing of iniuries, fasting, prayer, repentance [...]' (448-449); the last word is cancelled and the margin reads: 'penaunce'. 


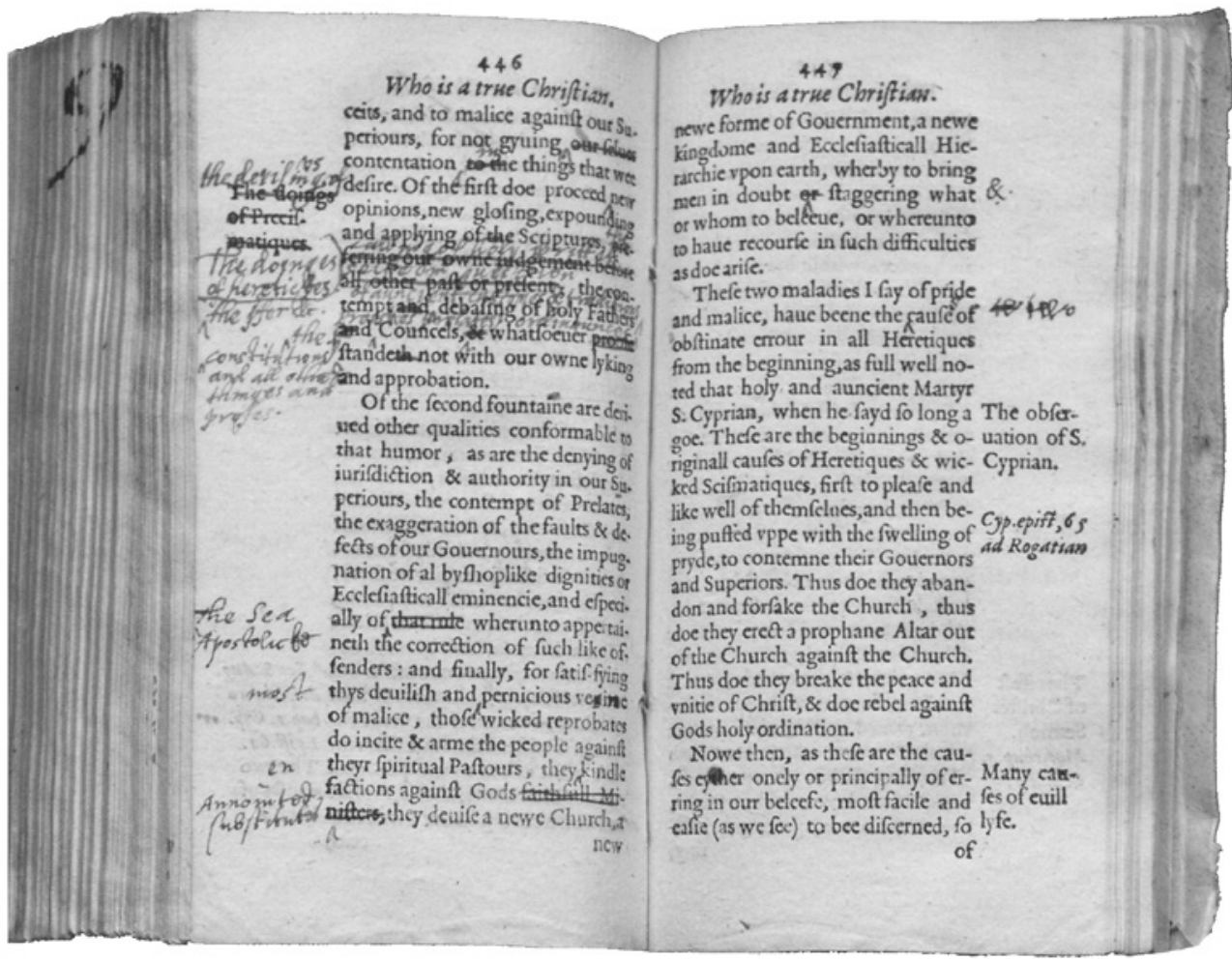

FIGURE 7.2 The Second part of the Booke of Christian exercise (London, Iohn Charlwood for Simon Waterson: 1592) 446. Royal Library of the Monastery of El Escorial

(C) PATRIMONIO NACIONAL

Of the second fountaine are deriued other qualities conformable to that humor, as are the denying of iurisdiction \& authority in our Superiours, the contempt of Prelates, the exaggeration of the faults \& defects of our Gouernours, the impugnation of al byshoplike dignities or Ecclesiasticall eminencie, and especially of that rule wherunto appertaineth the correction of such like offenders [...].64 [Fig. 7.2.]

Importantly, this passage discusses the origin of heresy. The intervention occurs at precisely the point at which the denial of church officials is designated a source of heresy. However, the fact that this and other passages in the Escorial copy of this Protestant appropriation of Persons's text only receive such verbally restrained reactions - if any - when they are particularly loaded with

64 The Second part (1592) 446; my emphasis. 
doctrinal significance, is uncharacteristic of refutation. The argumentative tone and polemical approach commonly found in refutational annotations is absent, nor is there any statement indicating a controversialist purpose. The difference can be seen readily by comparing Persons's disputatious reaction to what he considered as Bunny's mangling of the Book of Resolution in the preface to his Christian Directory:

And this shameles shift of corrupting other mens bookes, is an old occupation of heretiques from the beginning, as may appeare by the often complaintes of most ancient fathers, whos workes they were not ashamed to infect and corrupt whiles they were yet liuing. ${ }^{65}$

Or: in a section dedicated to resisting sin, Persons disputes Bunny's view in the apostille, giving a documented response:

Bunney doubteth vvhether S. Anthonie had sufficient groundvvorke of his doinge; but Athanasius doubted not. ${ }^{66}$

Persons reacts similarly to Bunny's alterations of certain terms to make them more acceptable for Protestants:

wher I talke of Catholique preestes that heare confessions; he maketh me saie, men that be skilful to giue Counsail, \&c. [...] In like maner page 368. When I saie, penance \& satisfaction. He maketh me saie, toile of amendment $[\ldots]$ turning euery wher the wordes penance and satisfaction into repentance. ${ }^{67}$

Persons's irate reactions to Bunny's appropriations illustrate the character of disputation practice as it had become established after the 'Great Controversy' between the Bishop John Jewel and Thomas Harding, and perpetuated for

65 Persons, A Christian directorie (1585) Preface 9v. Persons's preface is a rebuttal of Bunny's book developed through an extensive and detailed analysis of Bunny's techniques, from the deletions to the usage of parenthesis, among other alterations.

66 Ibidem 329. The comment is placed next to the following text: 'in this combat of resisting sinne, diuers other did afterward take in hand that strait course of life, wherof we read with admiration in auncie[n]t writers, as S. Anthonie, whos life is recorded by holy Athanasius'.

67 Persons, A Christian directorie (1585) Preface $11 \mathrm{r}$. 
decades in both oral and written dialectics. ${ }^{68}$ Clearly then, the annotations in the Escorial copy of The Second part aspire to a very different character and tone. Besides the substitution of terms, phrases, or, occasionally, brief passages, the anonymous hands have marked the text in several other ways, with insertions, transposition of elements, underlinings, as noted. These nonverbal interventions can hardly be considered a refutation of the text. Taken together, the verbal and non-verbal interventions with their generally understated doctrinal content in the Escorial copy of The Second part offer a broader scope of readerly responses than does standard controversy. ${ }^{69}$ Nevertheless, the annotations are more than mere reading notes, inasmuch as they modify (even if they do not directly rebut) the text of The Second part. In that regard, these readerly markings can be considered evidence of the kind of readers' engagement that William $\mathrm{H}$. Sherman has shown was common practice in the period, what he terms 'active reading': to 'mak[e] books their own by making marks in and around them and by using them for getting on in the world', thus 'transform [ing] one printed book into another'.70 In precisely this way the readers and annotators of the Escorial Second part 'customized' this Protestant book with a wide display of marks, investing it with an unquestionable Catholic essence that undoubtedly suited their own worldview.

Beyond the above-mentioned emendations, a very important part of the customization of the Escorial The Second part relies on, on the one hand, nonverbal interventions like underlinings, crossing-outs with no suggested emendation, or transposition marks; and, on the other, on smaller elements, from individual words to morphemes. Among the former - the non-verbal marks the symbols indicating transposition of words are outstanding inasmuch as they strongly call to mind proofreading activities. Actually, some of the pages in the volume visually resemble those to be found in what Anthony Grafton calls 'the kingdoms of error', printing houses where teams of correctors had a prominent role in emending typographical errors. ${ }^{71}$

68 Joshua R., Public Religious Disputation in England, 1558-1626 (Surrey; Burlington: 2014) esp. ch. 1; Questier M., Conversion, Politics and Religion in England, 1580-1625 (Cambridge: 1996); Milward P., Religious Controversies of the Elizabethan Age: A Survey of Printed Sources (Lincoln: 1977).

69 This is particularly so when it comes to underlinings and transpositions, where the doctrinal weight can hardly be appreciated.

70 Sherman W.H., Used Books: Marking Readers in Renaissance England (Philadelphia: 2010) 3, 7 .

71 Grafton A., The Culture of Correction in Renaissance Europe (London: 2011, ch. 2. (78ff)). It is interesting to note the similarities with some of the images of proofs of shops like Plantin's or Moretus' with those in the Escorial Second part. For a more literary approach to typographical errors, both as part of the process of book production and as platform 
A look at the one of the pages of the volume can illustrate not only the visual similarity of the corrected page but also the detail and variety of the corrections: the figure [Fig. 7.3a] shows the deletion of pronouns ('S. Paul himself'), of indefinite articles ('in an open audience'), transposition of words (inversion of the phrase 'before noted'), substitution of individual words ('forged' for 'feygned'; 'those' for 'theyr'), and the correction of verbal forms ('protested' instead of 'protesteth'). ${ }^{72}$

While the meticulousness and punctiliousness in these corrections seems to point at the 'minute scrutiny of the texts' typical of the 'sharp-eyed critics', as Grafton calls the proof-readers, ${ }^{73}$ it is obvious that the marks and annotations on these pages are not done in preparation for printing, as the work has already been printed, distributed, and a copy of the book has even travelled beyond the British Isles into the Iberian Peninsula. Therefore, it is the use of that printed book what we witness through the marks and annotations - here I am following Sherman's terminology for annotations as traces of 'use' of the book. ${ }^{74}$ The question is obviously what kind of use leaves traces of such a thorough correction and to what purpose. Grafton points at the systems of gifts and exchange as driving the zeal for correction in printing houses. Neither writers nor patrons were willing to have a book widely disseminated with a text that was inaccurate or distorted by the number of errors. In this case, it is not the producer, but the user who would not tolerate the errors. And although in appearance this situation might be similar to that of readers responding to lists of mistakes and appeals to correct them described by Adam Smyth, ${ }^{75}$ here errors have a new dimension. Errors in a religious work, and in the context of the battle of religious books, are particularly momentous. The wrong word could lead to the wrong belief, a concern with the exactitude of the letter that goes back centuries in time, in particular among Christians. ${ }^{76}$ That is actually what the usage of this book is about: the correction of what is not exact, of what is wrong, and therefore heterodox. The hands that annotate it, in their zeal for correction, apply the thoroughness of the collating techniques devised by the

for the literary authors' creativity, see Smyth A., Material Texts in Early Modern England (Cambridge: 2018) $75^{-136 .}$

72 The Second part (1592) $35^{8}$.

73 Grafton, The Culture of Correction 214.

74 Sherman, Used Books xiii.

75 Smyth, Material Texts 92-98.

76 The fear of misinterpretation lead to an anxiety for the "sensus literalis" of the Bible which was central to the controversies on the translation of the Bible. See the classic study on the topic Schwarz W., Principles and Problems of Biblical Translation: Some Reformation Controversies and their Background (Cambridge: 1955). 


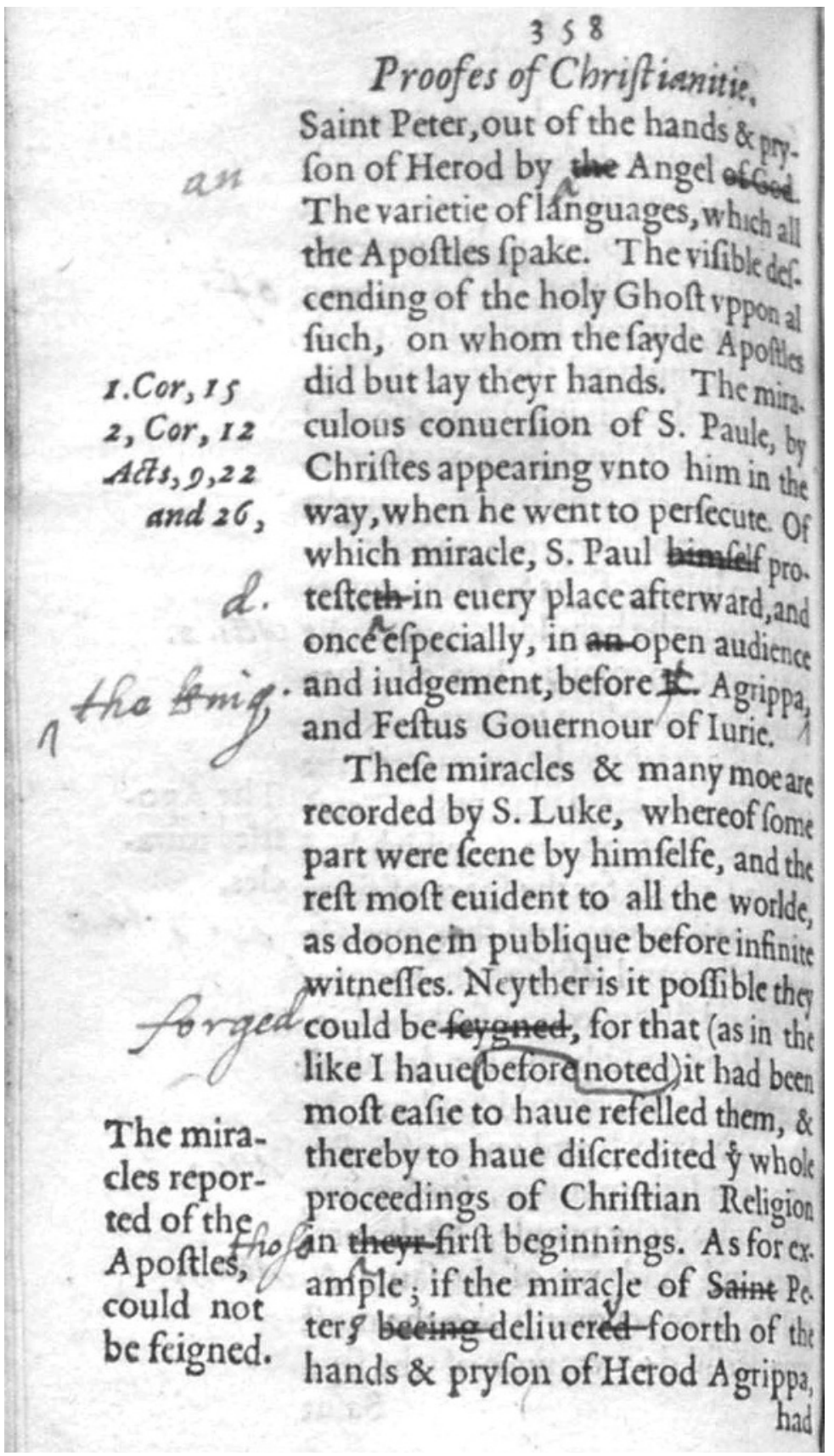

FIGURE 7.3A The Second part of the Booke of Christian exercise (London, Iohn Charlwood for Simon Waterson: 1592) 358. Royal Library of the Monastery of El Escorial (C) PATRIMONIO NACIONAL 
philological work of the humanists. ${ }^{77}$ Here, instead of a critical comparison of a number of manuscripts in an attempt to reach the best textual testimony/ reading, the correctors already have a sense of the original and the distortions it has gone through. Thus, the concern with the textuality ${ }^{78}$ and the literalness of the original is central to the English Catholic annotators ${ }^{79}$ who corrected the Escorial copy of the Protestant Second part, aware as they did so of the fact that the original to collate it with was Persons's Christian Directory. A comparison of the page 358 seen above, with a transcription of the corresponding text in Persons makes it evident:

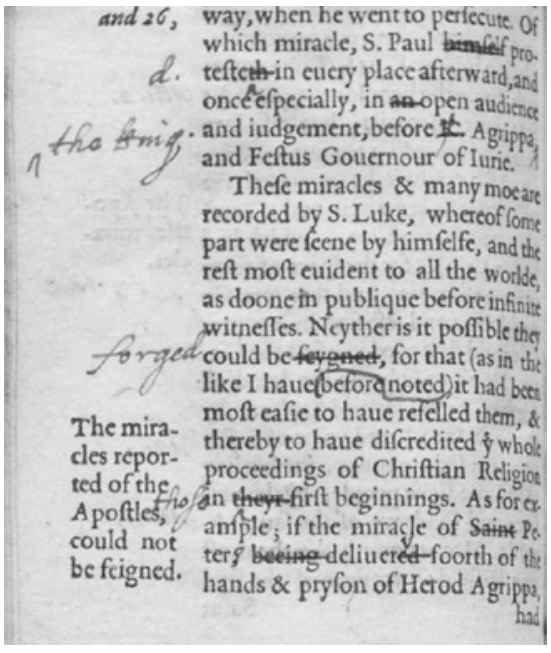

FIGURE 7.3B
[...] way when he went to persecute. Of which miracle, S. Paul protested in euery place afterward, and once especiallie, in open audience and iudgement before Agrippa the king, and Festus Gouernour of Iurie.

Thes miracles and manie moe are recorded by S. Luke; wherof some part were sene by him self, and the rest most euident to all the worlde, as done in publique before infinite witnesses. Neither is it possible they could be forged, for that (as in the like I haue noted before,) it had bene most easye to haue refelled them, and therby to haue discredited the whole proceedings of Christian religion, in thos first beginnings. As for example; if the miracle of Peters deliuery forth of the $[\ldots]{ }^{80}$

77 Italian humanists, from Leonardo Bruni to Angelo Poliziano made the word the center of knowledge, as Ernesto Grassi has argued (Einführung in philosophische Probleme des Humanismus. Wissenschaftliche Buchgesellschaft (Darmstadt: 1986) 46). See also Rico F., El sueño del humanismo: de Erasmo a Petrarca (Madrid: 2002) 85ff.

78 Richards J. - Schurink F., "The Textuality and Materiality of Reading in Early Modern England", Huntington Library Quarterly 73, 3 (2010) 345-361.

79 The meticulousness in the transmission and dissemination of texts was a common currency among English Catholics. See for instance Yale University, Beinecke Rare Book and Manuscript Library, Ms Obsborn a42.

8o Persons, $A$ Christian directorie (1585) 253-254. 
As can be observed, the annotators in the Escorial copy of The Second part, fully conscious of the manner in which the work distorts Persons's Christian Directory, have methodically contrasted the two of them in an aspiration to revert the anonymous Protestant appropriation, and hence to reconstruct the Catholic text to its original verbal choices, its morphology, even its word order, in an almost philological endeavour that only spares variant spelling and punctuation. The resulting text, once the annotator has meticulously restored it to its original 'orthodoxy', 81 would then be something that could be safely used without any tinge of 'heresy' - when no other copy of the Christian Directory was available. ${ }^{82}$ This result, in a way, was comparable to what was achieved by the Inquisition's expunging of books. ${ }^{83}$

This 'use' of the Escorial copy of The Second part, though technically not polemical, is however deeply related to recusant book culture in exile. As is well known, the dissemination of Catholic culture in England, and from England towards the Continent, not only relied on printed books - which could not be produced in England - but also, to a large extent, on manuscripts. ${ }^{84}$ And, while the continuity of manuscript culture in certain areas of textual production coexisted with the widespread printed texts in the English letters in general, ${ }^{85}$ the coexistence of one and the other was somewhat more interconnected in

81 Such is the zeal of the correctors that some actual typographical errors of the original edition which had been corrected in the 1592 Protestant version - errors completely devoid of any religious consequence - are restored to their mistaken form, just because that is the way they appear in the 1585 edition. That is the case of the name 'Baltasar' (The Second part 178), which corrects Persons's erroneous 'Balsasar' - an error that is recovered in the margin by the anonymous annotator.

82 I have also contemplated other hypotheses, like the possibility that the book was being marked-up for another Catholic reprinting of the Christian Directory, but this seems highly unlikely because the next edition to be published (1598) was identical to the first one, and the following one (1607) has much more significant changes none of which are marked in the annotations of the Escorial copy of The Second part.

83 Peña Díaz M., Escribir y prohibir: Inquisición y censura en los Siglos de Oro (Madrid: 2015) $23,36,48$.

84 See, among others, Havens E., "Notes from a Literary Underground: Recusant Catholics, Jesuit Priests, and Scribal Publication in Elizabethan England", The Papers of the Bibliographical Society of America 99, 4 (2005) 505-538. Nany Pollard Brown has studied how Catholic families collected 'manuscript and printed books for their libraries in country houses' ("Paperchase: the dissemination of Catholic texts in Elizabethan England", English Manuscript Studies 1 (1989) 120-143, here 122).

85 See, for instance, the usage of manuscripts for poetry as studied by Marotti A., Manuscript, Print, and the English Renaissance (Ithaca: 1995), and Woudhuysen H.R., Sir Philip Sidney and the Circulation of Manuscripts: 1558-1640 (Oxford - New York: 2003). For the seventeenth century, see Love H., Scribal Publication in Seventeenth-Century England (Oxford - New York: 2001). 
the context of English Catholics in particular, both in England and in exile. In Luis de Granada's words, books had become 'domme preachers' for Catholics in England. ${ }^{86}$ The networks of English Colleges on the Continent made extensive use of both manuscripts and printed texts for the dissemination of all kinds of information, from the news on the persecution and martyrdom, ${ }^{87}$ to multiple copies of devotional, controversial and even political for wide distribution among the members of a persecuted community. Certainly, the two supplemented each other: while the printing press ensured the distribution of a high number of copies, the scribal production could sometimes be more suitable for faster or clandestine dissemination. But at the same time, print and manuscript were not in competition nor were they mutually exclusive. There was a fluid relationship between printed and manuscript text, which not only coexisted but also combined, not infrequently in a seamless unison. As Walsham has variously argued, these forms of hybridity significantly contributed to the proselytizing purpose of training in colleges on the Continent. ${ }^{88}$

The Escorial copy of The Second part is an extraordinary survival illustrating how the printed and the scribal cultures were instrumental for English Catholics outside England, more specifically in their exile in Spain. The use that can be traced through the marks and annotations in it had in all likelihood a utilitarian character which suited the needs of those persecuted Catholics who, while in England, had to circumvent the prohibition of publishing books, and in exile, had to depend on agents like Verstegan and their networks of dissemination in order to have access to books in their own language both for devotion and training for priesthood. In this context of difficult access to written resources on the one hand, and need for them for professional purposes on the other, the culture of recycling and repurposing became one more survival strategy. It is well known that many documents that were no longer of interest, or were considered old, useless or dated, ended up reused as binding material. ${ }^{89}$ Similarly, the books and texts themselves were repurposed for new uses in a variety of manners. From that perspective, Bunny's 'perusal' of

86 Alexandra Walsham has studied the significant role that books had for Catholics in England, especially in the absence of books: "Domme Preachers'? Post-Reformation English Catholicism and the Culture of Print", Past \& Present 168 (2000) 72-123.

87 Dillon A., The construction of martyrdom in the English Catholic community, 1535-1603 (Aldershot: 2002); McCoog T.M., "Construing Martyrdom in the English Catholic Community, 1582-1602”, in Shagan E. (ed.), Catholics and the 'Protestant Nation': Religious Politics and Identity in Early Modern England (Manchester: 2005) 95-127; and Monta S., Martyrdom and Literature in Early Modern England (Cambridge: 2005).

88 Walsham, "The Spider and the Bee" 189.

89 The instances of reuse of material are numerous. For the recusant context, see for instance the so-called Desiderius, in the Beinecke library, which has a fragment of a 
Persons's Book of Christian Exercise can be considered one of the most noteworthy instances inasmuch as it modifies the original text into a new one for a different purpose. Similar instances would be a not insignificant number of Protestant translations and adaptations of Spanish Catholic texts into English, as well as Catholic devotional manuscripts used by Protestants for their own devotion, with but a few additional notes and comments. ${ }^{90}$ It is against this background of the practice of recycling that the marks and annotations in the Escorial copy of The Second part should be understood. The book that is now in the royal library was among the Protestant books that English Catholic exiles like Wadsworth or Price were asked to examine for the Inquisition and was then incorporated to one of their personal libraries. In a culture of economy of resources, when books such as Persons's original Book of Christian Exercise were in demand for Catholic exiles, the idea of recycling the seized copy of The Second part by way of correcting the Protestant appropriations and reverting it to Persons's own text through a process of collation and scribal reconstruction thus constitutes a utilitarian (re)use of the book. ${ }^{91}$

Seen in this light, the repurposing carried out in the markings and annotations in the book responds to specific ends, interests and needs that are comparable to the ones described by Lisa Jardine and Anthony Grafton. In their analysis of early modern annotations, they reveal how many of they were goal-directed by professional readers by like Gabriel Harvey, who approached the book 'to give rise to something else'. ${ }^{22}$ In the case of the Escorial Second part, obviously the annotations are not intended for political, social or military promotion, nor even as tools for controversial purposes, or for religious persecution (in the manner of Richard Topcliffe). ${ }^{93}$ Rather, they constitute a carefully planned job of meticulous corrections which are unquestionably specialized for religious use. This plan was put together by readers

liturgical manuscript used as binding guard (ms Osborn a32). For an analysis of the new life of these recycled 'waste' into new books, see Smyth, Material Texts 143-153.

9o For an overview, see Yamamoto-Wilson "The Protestant Reception of Catholic Devotional Literature". Some specific reuses of devotional texts have been studied by McQuade P., Catechisms and Women's Writing in Seventeenth-Century England (Cambridge: 2017) esp. part 2.

91 In a way, not unlike the instances of scribal copying of printed texts intended for dissemination: see Havens, on the copies commissioned by Arundel ("Notes from a Literary Underground"). On the utilitarian use of books, see Richards - Schurink "The Textuality and Materiality of Reading".

92 Jardine L. - Grafton A., “Studied for Action': How Gabriel Harvey Read His Livy”, Past \& Present 129 (1990) 30-78, here 3 o.

93 Rankin M., "Richard Topcliffe and the Book Culture of the Elizabethan Catholic Underground", Renaissance Quarterly 72, 2 (2019) 492-536. 
familiarized with the techniques used by the Spanish Inquisition in order to check any possible trace of heterodoxy in the texts they examined, and to act following the indications of the index of forbidden books, and, in the absence of those indications, to ensure the books were heresy-proof. The result, in the Escorial copy of The Second part, exceeds by far the inquisitorial zeal: not only is the text completely free from heretical terms and ideas, but it aspires to restore Persons's exact words, resulting in a text hardly distinguishable from the original. ${ }^{94}$ Once completed, the repurposed book could be used again by those English Catholics who find it difficult to get copies of The Christian Directory in Spain. One of the most remarkable effects of this recycling, interestingly enough, is that it puts an end to the consecutive layers of instability that accumulated, first with Persons's version of the Resolution, then with Bunny's appropriation, followed by Persons's revision and rebuttal of Bunny in The Christian Directory, and finally, with the anonymous Protestantisation. The process might be compared to a set of Russian dolls that the annotators of the Escorial copy of The Second part intended to stabilize with their recovery of the original authority of the text. This is the same authority that, according to Ronald Corthell, Persons was intent on establishing in his writings, in the belief that minimizing reading instability would be crucial for the missionary activity. ${ }^{95}$ It becomes clear that this concern of Persons's was recognized and adopted by Catholics in exile, and those who were trained for the mission. The zeal in the restoration of Persons's text in the Escorial copy of The Second part is an utmost exercise of recovery of the textual authority so that the original work could be read in Spain.

\section{Bibliography}

\section{Primary Sources}

Bancroft Richard, A suruay of the pretended holy discipline [...] (London, Iohn Wolfe: 1593).

The Booke of common prayer (London, Christopher Barker: 1578).

Bright Timothy, Therapeutica (Frankfurt, John Wechel:1589).

Bunny Edmund, A booke of Christian exercise, appertaining to resolution [...] by R.P. Perused, and accompanied now with a treatise tending to pacification: by Edm. Bunny (London, N. Newton: 1584).

94 This is so in those sections that have been maintained from Persons's text. See above (pp. 162-163) for the structural differences between the Christian Directory and The Second part.

95 Corthell R., "Politics and Devotion. The Case of Robert Persons vs. Edmund Bunny, Author of A Book of Christian Exercise", Journal of Jesuit Studies 1 (2014) 558-571, here 561. 
Bunny Edmund, A briefe answer, vnto those idle and friuolous quarrels of $R[$ obert $]$ $P[$ ersons $]$ against the late edition of the Resolution (London, Iohn Charlewood: 1589).

Camden William, Britannia (Frankfurt, John Wechel: 159o).

Cheke John, De pronuntiatione graecae (Basel, Nicholas Episcopius, Jr.: 1555).

Foxe John, Actes and monuments (London, Iohn Day: 1563).

Loarte Gaspar, The Exercise of a Christian Life, trans. Stephen Brinkley (London, W. Carter: 1579).

Norden John, A pensiue mans practise, verie profitable for all persons [...] (London, Robert Robinson: 1597).

Persons Robert, First booke of the Christian exercise, appertayning to resolution. Viverein are layed downe the causes \& reasons that should moue a man to resolue hym selfe to the seruice of God (Rouen, Persons's press: 1582).

Persons Robert, A christian directorie guiding men to their salvation. Deuided into three Bookes ([Rouen, Persons's press]: 1585).

Persons Robert, A christian directorie guiding men to their salvation devided into three boores [i.e. bookes] (Louan, Laurence Kellam: 1598).

Persons Robert, Relacion que embiaron las religiosas del Monesterio de Sion de Inglaterra (Madrid: biuda de P. Madrigal, 1594).

Persons Robert, Relacion de un sacerdote ingles, escrita a Flandes, a un cavallero de su tierra, desterrado por ser católico (Madrid: Pedro Madrigal, 1592).

Persons Robert A briefe apologie, or Defence of the Catholike Ecclesiastical Hierarchie [...] ([Antwerp, Arnout Conincx]: [1601]).

Persons Robert, The Correspondence and Unpublished Papers of Robert Persons, SJ. 1, 1574-1588, ed. V. Houliston (Toronto: 2017).

Persons Robert, The Christian directory (1582): The first booke of the Christian exercise, appertayning to resolution, ed. V. Houliston (Leiden - Boston: 1998).

Quiroga Gaspar de, Index et catalogus Librorum prohibitorum (Madrid: Alphonso Gómez, 1583).

The Second part of the Booke of Christian exercise, appertayning to Resolution or a Christian directory, guiding all men vnto theyr saluation and ed. (London: John Charlewood, 1592).

The Seconde parte of the Booke of Christian exercise, appertayning to Resolvtion. Or a Christian directorie, guiding all men to their saluation (London, Iohn Charlwoode and Simon Waterson: 1590).

Turnbull Richard, An exposition vpon the canonicall epistle of Saint Iames (London, John Windet: 1591).

\section{Secondary Sources}

Alloza Á., "Comercio y rivalidad entre España e Inglaterra. Corso, ataques navales y represalias en los siglos XVI y XVII", XVII Coloquio de Historia Canario-americana (Las Palmas de Gran Canaria: 2006) 1642-1688. 
Arblaster P., Antwerp \& the World. Richard Verstegan and the International Culture of Catholic Reformation (Leuven: 2004).

Bowden C., "Building Libraries in Exile: The English Convents and their Book Collections in the Seventeenth Century", British Catholic History 32, 3 (2015) 343-382.

Corthell R., "Politics and Devotion. The Case of Robert Persons vs. Edmund Bunny, Author of A Book of Christian Exercise", Journal of Jesuit Studies 1 (2014) 558-571.

Corthell R., "Writing Back: Robert Persons and the Early Modern English Catholic Subject", Philological Quarterly 87, 3-4 (2008) 277-297.

Croft P., "Englishmen and the Spanish Inquisition", The English Historical Review 87, 343 (1972) 249-268.

Croft P., "Trading with the Enemy, 1585-1604", Historical Journal 32, 2 (1989) 281-302.

Cummings B., "Shakespeare and the Inquisition", in Holland P. (ed.), Shakespeare Survey 65 (2012) 306-322.

Dillon A., The Construction of Martyrdom in the English Catholic Community, 1535-1603 (Aldershot: 2002).

Dobranski S.B., Readers and Authorship in Early Modern England (Cambridge - New York: 2005).

Driscoll J.P., "The Seconde Parte: Another Protestant Version of Robert Persons's Christian Directorie", Huntington Library Quarterly 25 (1962) 139-146.

Gómez Canseco L., El humanismo después de 1600: Pedro de Valencia (Sevilla: 1993).

Gonzalo Sánchez-Molero J.L., "La biblioteca de Arias Montano en El Escorial", in Maestre Maestre J.M. et al. (eds.), Benito Arias Montano y los humanistas de su tiempo (Mérida: 2006), vol. 1, 91-110.

Grafton A., The Culture of Correction in Renaissance Europe (London: 2011).

Grassi E. Einführung in philosophische Probleme des Humanismus. Wissenschaftliche Buchgesellschaft (Darmstadt: 1986).

Gregory B.S., "The 'True and Zealouse Service of God': Robert Parsons, Edmund Bunny, and the First Booke of the Christian Exercise", Journal of Ecclesiastical History 45 (1994) 238-268.

Havens E., "Notes from a Literary Underground: Recusant Catholics, Jesuit Priests, and Scribal Publication in Elizabethan England", The Papers of the Bibliographical Society of America 99, 4 (2005) 505-538.

Houliston V., Catholic Resistance in Elizabethan England: Robert Persons's Jesuit Polemic, 1580-1610 (Aldershot: 2007).

Houliston V., "Why Robert Persons would not be Pacified. Edmund Bunny's Theft of The Book of Resolution", in McCoog T.M. (ed.), The Reckoned Expense: Edmund Campion and the Early English Jesuits (Woodbridge: 1996) 159-177.

Houliston V., “Re-Considering 'Consideration' with Robert Persons”, Reformation 24, 1 (2019) 24-42.

Houliston V., "Persons Cannibalized Again”, Notes \& Queries 44 (1997) 32-33. 
Jardine L. - Grafton A., “'Studied for Action': How Gabriel Harvey Read His Livy”, Past \& Present 129 (1990) 30-78.

Joshua R., Public Religious Disputation in England, 1558-1626 (Surrey - Burlington: 2014). Lezcano Tosca H., "Lecturas espirituales prohibidas en la Real Biblioteca de El Escorial (siglo XVI)", Libros de la Corte.es 6 (2013) 76-120.

Love H., Scribal Publication in Seventeenth-Century England (Oxford - New York: 2001). Marotti A., Manuscript, Print, and the English Renaissance (Ithaca: 1995).

Martínez de Bujanda J. et al., Thesaurus de la littérature interdite au XVI siècle: auteurs, ouvrages, éditions avec addenda et corrigenda (Paris: 1996).

Martínez de Bujanda J., El índice de libros prohibidos y expurgados por la Inquisición española (1551-1819) (Madrid: 2016).

McCoog T.M., “'Guiding Souls to Goodness and Devotion': Clandestine Publications and the English Jesuit Mission", in Bela T. - Calma C. - Rzegocka J. (eds.), Publishing Subversive Texts in Elizabethan England and the Polish-Lithuanian Commonwealth (Leiden: 2016) 91-109.

McCoog T.M., English and Welsh Jesuits: 1555-1650 ([London]: 1994).

McCoog T.M., "Playing the Champion': The Role of Disputation in the Jesuit Mission", in McCoog T.M. (ed.), The Reckoned Expense: Edmund Campion and the Early English Jesuits (Woodbridge: 1996) 119-140.

McCoog T.M., "Construing Martyrdom in the English Catholic Community, 1582-1602", in E. Shagan (ed.), Catholics and the 'Protestant Nation': Religious Politics and Identity in Early Modern England (Manchester: 2005) 95-127.

McCoog T.M., The Society of Jesus in Ireland, Scotland and England, 1589-1597. Building the Faith of St Peter upon the King of Spain's Monarchy (Leiden: 2012).

McNulty R., Robert Parsons's The First Booke of the Christian Exercise (1582). An Edition and a study (Ph.D. dissertation Columbia University: 1955).

McNulty R., “The Protestant Version of Robert Parsons' The First Booke of the Christian Exercise", Huntington Library Quarterly 22 (1959) 271-30o.

McQuade P., Catechisms and Women's Writing in Seventeenth-Century England (Cambridge: 2017).

Milward P., Religious Controversies of the Elizabethan age: A Survey of Printed Sources (Lincoln: 1977).

Monta S., Martyrdom and Literature in Early Modern England (Cambridge: 2005).

Murphy G.M., "Wadsworth, James (c. 1572-1623)", Oxford Dictionary of National Biography. 23 Sep. 2004; Accessed 15 Jan 2020. https://www.oxforddnb.com/view/ 10.1093/ref:odnb/9780198614128.oo1.ooo1/odnb-9780198614128-e-28389.

Murphy M., St Gregory's College, Seville, 1592-1767 (London: 1992).

Peña Díaz M., Escribir y prohibir: Inquisición y censura en los Siglos de Oro (Madrid: 2015). 
Pollard Brown N., "Paperchase: The Dissemination of Catholic Texts in Elizabethan England", English Manuscript Studies 1 (1989) 120-143.

Questier M., Conversion, Politics and Religion in England, 1580-1625 (Cambridge: 1996). Rankin M., "Richard Topcliffe and the Book Culture of the Elizabethan Catholic Underground", Renaissance Quarterly 72, 2 (2019) 492-536.

Richards J. - Schurink F., "The Textuality and Materiality of Reading in Early Modern England", Huntington Library Quarterly 73, 3 (2010) 345-361.

Rico F., El sueño del humanismo: de Erasmo a Petrarca (Madrid: 2002).

Schwarz W., Principles and Problems of Biblical Translation: Some Reformation Controversies and their Background (Cambridge: 1955).

Sáez-Hidalgo A., "Extravagant' English Books at the Library of El Escorial and the Jesuit agency", in Kelly J.E. - Thomas H.J. (eds.), Jesuit Intellectual and Physical Exchange between England and Mainland Europe, c.1580-1789. "The World is our House? (Leiden: 2019) 155-185.

Sáez-Hidalgo A., "English Recusant Controversy in Spanish Print Culture: Dissemination, Popularization, Fictionalization", in Chambers L. and O'Connor T. (eds.), Forming Catholic Communities: Irish, Scots and English College Networks in Europe, 1568-1918 (Leiden: 2018) 201-231.

Sherman W.H., Used Books: Marking Readers in Renaissance England (Philadelphia: 2010).

Smyth A., Material Texts in Early Modern England (Cambridge: 2018).

Sullivan C., "Cannibalizing Persons's Christian directorie, 1582", Notes \& Queries 41 (1994) 445-446.

Walsham A. - Havens E., "Catholic Libraries: An Introduction", in Fehrenbach R.J. et al. (eds.), Private Libraries in Renaissance England: A Collection and Catalogue of Tudor and Early Stuart Book-Lists, vol. 8 (Tempe: 2014) 129-261.

Walsham A., "Domme Preachers'? Post-Reformation English Catholicism and the Culture of Print", Past \& Present 168 (2000) 72-123.

Walsham A., "The Spider and the Bee: The Perils of Printing for Refutation in Early Tudor England", in King J.N. (ed.), Tudor Books and Readers: Materiality and the Construction of Meaning (Cambridge: 2010) 163-19o.

Woudhuysen H.R., Sir Philip Sidney and the Circulation of Manuscripts: 1558-1640 (Oxford - New York: 2003).

Yamamoto-Wilson J.R., "Robert Persons's Resolution (1582) and the Issue of Textual Piracy in Protestant Editions of Catholic Devotional Literature", Reformation and Renaissance Review 15, 2 (2013) 177-198.

Yamamoto-Wilson J.R., "The Protestant Reception of Catholic Devotional Literature in England to 1700", British Catholic History 32, 1 (2014) 67-9o. 